\author{
(CL. I. Berlinska, V. G. Marichereda, O. M. Pavlovska, Y. Y. Petrovskiy \\ Odesa National Medical University
}

\title{
ANTERIOR PLACENTA POSITION AS A CAUSING FACTOR OF PRE-ECLAMPSIA
}

The aim of the study - to determine the frequency of preeclampsia in pregnant females with anterior location of the placenta and to determine the prognostic significance when combined with a marker of acute renal damage - cystatin C level.

Materials and Methods. In 2018-2020, a prospective cohort study that enrolled 91 pregnant women at their second trimester of gestation was conducted at Maternity Clinic and Obstetric Hospital of Maternity Hospital No. 2, Odesa. The group with the anterior location of the placenta consisted of $47(51.65 \%)$ pregnant women and $44(48.35 \%)$ had the posterior location of the placenta. Assessment of serum cystatin $C$ was performed in women without clinical manifestations of PE at the second or third trimester of gestation (18-36 weeks), the average term was $(32.22 \pm 0.41)$ weeks of pregnancy $(p=0.011)$.

Results and Discussion. $28.57 \%$ of pregnant women were subsequently diagnosed with preeclampsia (PE), of whom 19 (20.88\%) had anterior and 7 (7.69\%) posterior placenta location. Body mass index (BMI) before pregnancy, age, and height: no statistically significant difference observed between groups ( $p>0.05)$. Analysis of maternal factors of PE in relation to the anterior location of the placenta: odds ratio (OR) higher than 1.0 was noted for combination with obesity (OR $2.38(95 \% \mathrm{Cl} 0.75-7.53)$ ), the age over 35 years (OR 1.01 (95\% Cl 0.41-2.49)) and history of PE during previous pregnancy (OR 1.38 (95\% Cl 0.21-9.01)), but no statistical significance was observed $(p>0.05)$. When analyzing cystatin $C$ values over $1.0 \mathrm{mmol} / \mathrm{l}$ relative to the anterior location of the placenta, the OR was $3.92(95 \% \mathrm{Cl} 1.45-10.57)$, sensitivity $84.09 \%$, specificity $42.55 \%$, accuracy $62.64 \%$ were reported, $p=0.011$. When analyzing the frequency of preeclampsia in the anterior location of the placenta, the OR was 3.59 (95 $\%$ Cl 1.32 - 9.71), sensitivity $84.09 \%$, specificity $40.43 \%$, accuracy $61.54 \%$ were reported with statistical significance $p=0.019$.

Conclusions. The risk of preeclampsia in patients with the anterior location of the placenta increases by 3.59 times with a prognostic accuracy of $61.54 \%$. To increase the prognostic significance for the detection of preeclampsia in women with anterior location of the placenta, it is recommended to assess the serum level of cystatin C.

Key words: preeclampsia; anterior location of the placenta; cystatin C; screening.

\section{ПЕРЕДНЕЕ РАСПОЛОЖЕНИЕ ПЛАЦЕНТЫ В КОНТЕКСТЕ ФАКТОРА ПРЕЭКЛАМПСИИ}

Цель исследования - определить частоту развития преэклампсии (ПЭ) у беременных с передним расположением плаценты и определить прогностическую значимость в комплексе с маркером острого повреждения почек - цистатином С.

Материалы и методы. На базе женской консультации и акушерского стационара КУ Роддом № 2 г. Одессы в 20182020 гг. было проведено проспективное когортное исследование 91 беременных женщин во втором триместре гестации. Группу с передним расположением плаценты составили 47 (51,65 \%) беременных женщин и 44 (48,35 \%) - с расположением плаценты по задней стенке матки. Исследование сывороточного цистатина С проводили у женщин без клинических проявлений ПЭ во втором или третьем триместре гестации (18-36 недель), средний срок составил $(32,22 \pm 0,41)$ недели беременности $(p=0,011)$.

Результаты исследования и их обсуждение. У 28,57 \% беременных женщин в дальнейшем диагностировали преэклампсию (ПЭ), из них у 19 (20,88 \%) переднее и у 7 (7,69 \%) заднее плацентарное расположение. В базовых характеристиках индекса массы тела (ИМТ) до беременности, возраста и роста между группами женщин с передним расположением плаценты, в зависимости от наличия ПЭ, статистической достоверности не отмечено $(p>0,05)$. При анализе материнских фракторов развития ПЭ при переднем расположении плаценты отношение шансов (ОШ) более 1,0 отмечено при сочетании с ожирением (ОШ 2,38 (95 \% Cl 0,75-7,53)), возрастом беременной более 35 лет (ОШ 1,01 (95 \% Cl 0,41-2,49)) и ПЭ во время предыдущей беременности (ОШ 1,38 (95 \% ди 0,21-9,01)) - статистической достоверности не отмечено (р>0,05). При анализе показателей цистатина С более 1,0 ммоль/л при переднем расположении плаценты ОШ составило 3,92 (95\% Cl 1,45-10,57), чувствительность 84,09 \%, специсичность 42,55 \%, точность 62,64 \%, p=0,011. При анализе частоты развития преэклампсии при переднем расположении плаценты ОШ составило 3,59 (95 \% Cl 1,32-9,71), чувствительность 84,09 \%, специсичность 40,43 \%, точность 61,54 \%, статистическая достоверность p=0,019.

Выводы. Риск развития преэклампсии при переднем расположении плаценты увеличивается в 3,59 раза с прогностической точностью до 61,54 \%. Для повышения прогностической значимости по выявлению преэклампсии у женщин с передним расположением плаценты целесообразным является определение показателей сывороточного цистатина С.

Ключевые слова: преэклампсия; переднее расположение плаценты; цистатин С; скрининг.

\section{ПЕРЕДНЄ РОЗТАШУВАННЯ ПЛАЦЕНТИ В КОНТЕКСТІ ЧИННИКА ПРЕЕКЛАМПСІЇ}

Мета дослідження - визначити частоту розвитку прееклампсії (ПЕ) у вагітних із переднім розташуванням плаценти та 3'ясувати прогностичну значимість у комплексі з маркером гострого пошкодження нирок - цистатином С.

Матеріали та методи. На базі жіночої консультації та акушерського стаціонару КУ Пологовий будинок № 2 м. Одеси у 2018-2020рр. було проведено проспективне когортне дослідження 91 вагітної жінки у другому триместрі гестації. Групу з переднім розташуванням плаценти склали 47 (51,65 \%) вагітних жінок та 44 (48,35 \%) - із розташуванням плаценти по задній стінці матки. Дослідження сироваткового цистатину С проводили у жінок без клінічних проявів ПЕ у другому або третьому триместрі гестації (18-36 тижнів), середній термін склав $(32,22 \pm 0,41)$ тижня вагітності $(p=0,011)$.

Результати дослідження та їх обговорення. У 28,57 \% вагітних жінок у подальшому діагностували прееклампсію (ПЕ), із них у 19 (20,88 \%) переднє та у 7 (7,69 \%) заднє плацентарне розташування. У базових характеристиках індексу 
маси тіла (IMT) до вагітності, віку та зросту між групами жінок із переднім розташуванням плаценти залежно від наявності ПЕ статистичної достовірності не відзначено (р>0,05). При аналізі материнських чинників розвитку ПЕ при передньому розташуванні плаценти відношення шансів (ВШ) більше 1,0 відзначено при поєднанні з ожирінням (BШ 2,38 (95 \% Cl 0,757,53)), віком вагітної більше 35 років (ВШ 1,01 (95 \% Cl 0,41-2,49)) та з ПЕ під час попередньої вагітності (ВШ 1,38 (95 \% ДІ 0,21-9,01)), але статистичної достовірності не відзначено (р>0,05). При аналізі показників цистатину С більше 1,0 ммоль/л щодо переднього розташування плаценти ВШ склало 3,92 (95 \% Cl 1,45-10,57), чутливість 84,09 \%, специфрічність 42,55 \%, точність 62,64 \%, p=0,011. При аналізі частоти розвитку прееклампсії при передньому розташуванні плаценти ВШ склало 3,59 (95\% Cl 1,32-9,71), чутливість 84,09 \%, специсрічність 40,43 \%, точність 61,54 \% зі статистичною достовірністю р=0,019.

Висновки. Ризик розвитку прееклампсії при передньому розташуванні плаценти збільшується у 3,59 раза із прогностичною точністю до 61,54 \%. Для підвищення прогностичної значимості щодо виявлення прееклампсії у жінок із переднім розташуванням плаценти доцільним $€$ визначення показників сироваткового цистатину С.

Ключові слова: прееклампсія; переднє розташування плаценти; цистатин С; скринінг.

INTRODUCTION. The International Unions of Obstetrics and Gynecology pay special attention to factors that cause the development of preeclampsia (PE) - one of the most important diseases of pregnant women, leading to maternal and perinatal morbidity and mortality. Modern complex PE screenings are based on case history, biomarkers and Dopplerography of uterine arteries [1]. The International Society of Ultrasonograpy in Obstetrics and Gynecology (ISUOG) recommends the use of a pulsation index to study uterine artery resistance in the context of PE screening [2]. Use of multi-parameter complex models that include Doppler imaging of the uterine arteries, enables $90 \%$ accuracy of early PE detection [3]. According to the algorithm of the Fetal Medicine Foundation (FMF), which combines maternal factors, mean blood pressure, pulsation index of uterine arteries and placental growth factor, the probability of developing PE before 37 gestation weeks is as high as $75 \%$ [4]. It is assumed that the development of maternal PE syndrome during second and third trimesters is facilitated by abnormal placentation at the beginning of the first trimester [5]. As a result, it leads to histological and morphological changes in the pre-eclampsy placenta (placental and vascular villi lesions, myocardial infarction and calcification, retro-placental hematoma, umbilical cord marginal position) [6]. Considering the anatomical features of the uterine blood supply and based on placental theory, it is possible to assume a relationship between the location of the placenta and preeclampsia. The location of the placenta within the uterus is determined by ultrasound from gestation week 15-16. The use of ultrasound as a tool for PE screening meets the basic requirements: availability, low cost, non-invasiveness and high specificity and sensitivity in complex models.

THE AIM OF THE STUDY - to determine the frequency of preeclampsia in pregnant females with anterior location of the placenta and to determine the prognostic significance when combined with a marker of acute renal damage - cystatin C level.

MATERIALS AND METHODS. In 2018-2020, a prospective cohort study of 91 pregnant women in the second trimester of gestation was evaluated in the clinic and obstetric hospital at Maternity Hospital No. 2, Odesa. The group with anterior position of placenta consisted of 47 (51.65\%) pregnant females; 44 (48.35\%) females had posterior position of placenta. PE was determined according to the recommendations of the International Society for the Study of Hypertension in Pregnancy: systolic blood pressure $\geq 140 \mathrm{~mm}$ $\mathrm{Hg}$ or diastolic pressure $\geq 90 \mathrm{~mm} \mathrm{Hg}$ when measured at least 2 times every 4 hours in females who had normal blood pressure before pregnancy, with one or more of the following conditions detected after gestation week 20: proteinuria, acute renal failure, acute liver failure, neurological or hematological complications, uteroplacental dysfunction [7]. Thus, $28.57 \%$ of pregnant women belong to the subgroup with PE and $71.43 \%$ - women who had not developed PE.

Thus, $28.57 \%$ of pregnant women belong to the subgroup with PE and $71.43 \%$ - women who had no developed PE.

Ultrasound assessment of the location of the placenta was performed at 18-20 weeks of gestation using a universal device of ultrasound examination "Toshiba Aplio 400" (Japan).

Studies of serum cystatin C level were conducted in females without clinical manifestations of PE during the second or third trimester of gestation (18-36 weeks), the average term was $(32.22 \pm 0.41)$ weeks of pregnancy $(p=0.011)$.

Statistical analysis.

The data obtained in the study were entered into the MS-Excel database and analyzed using the statistical program MedCalc for PC, version 12.7.0 (MedCalc Software, Belgium). Between group comparisons were performed by one of the methods of ANOVA. To identify the relationship of the most significant factors, the odds ratio (OR) is calculated, with values greater than 1.0, a direct relationship is observed. $P$ value $<0.05$ was considered statistically significant.

RESULTS AND DISCUSSION. Preeclampsia was developed in 26 (28.57\%) pregnant females, $19(20.88 \%)$ of them had anterior position of placenta and 7 (7.69\%) had posterior placenta location.

Body mass index (BMI) before pregnancy, age, and height of women with anterior location of the placenta were not associated with statistically significant probability of PE development $(\mathrm{p}>0.05)$ (Table 1$)$.

Odds ratio (OR) greater than 1.0 was noted for combination of PE with obesity (OR 2.38 (95 \% Cl 0.75-7.53)), age over 35 years (OR 1.01 (95\% Cl 0.41-2.49)) (Table 2) and history of PE during previous pregnancy (OR 1.38 (95\% Cl 0.21-9.01)) (Table 3), but no statistical significance was observed $(p>0.05)$.

It can be assumed that none of the maternal factors of PE, such as maternal PE, chronic hypertension, history of renal disease, first pregnancy, and the interval between pregnancies $>10$ years, is not related to the location of the placenta as a factor of preeclampsia development.

In our previous study of renal biomarkers cystatin C was identified as a predictor of PE development during the second and third trimesters. It has been demonstrated that cystatin 
Table 1. Characteristics of age, height and BMI of pregnant women with preeclampsia or without preeclampsia depending on the location of the placenta

\begin{tabular}{|c|c|c|c|c|c|c|}
\hline \multirow{3}{*}{ Preeclampsia } & \multicolumn{2}{|c|}{ Maternal age, years } & \multicolumn{2}{|c|}{ Height, $\mathrm{cm}$} & \multicolumn{2}{|c|}{ BMI } \\
\hline & \multicolumn{2}{|c|}{ Placenta location } & \multicolumn{2}{|c|}{ Placenta location } & \multicolumn{2}{|c|}{ Placenta location } \\
\hline & Posterior & Anterior & Posterior & Anterior & Posterior & Anterior \\
\hline Without PE & $\begin{array}{c}30.89 \pm 0.99 \\
95 \% \mathrm{Cl}: \\
28.94-32.84 \\
\mathrm{n}=37\end{array}$ & $\begin{array}{c}29.93 \pm 1.06 \\
95 \% \mathrm{Cl}: \\
27.86-32 \\
\mathrm{n}=28\end{array}$ & $\begin{array}{c}168.38 \pm 0.81 \\
95 \% \mathrm{Cl}: 166.79- \\
169.96 \\
n=37\end{array}$ & $\begin{array}{c}165.71 \pm 2.1 \\
95 \% \text { Cl: } 161.59- \\
69.83 \\
n=28\end{array}$ & $\begin{array}{c}24.35 \pm 0.85 \\
95 \% \mathrm{Cl}: \\
22.69-26.01 \\
n=37\end{array}$ & $\begin{array}{c}24.43 \pm 1.12 \\
95 \% \text { Cl: } 22.24- \\
26.62 \\
n=28\end{array}$ \\
\hline With PE & $\begin{array}{c}29.29 \pm 1.48 \\
95 \% \mathrm{Cl}: \\
26.39-32.18 \\
n=7\end{array}$ & $\begin{array}{c}31.16 \pm 1.62 \\
95 \% \mathrm{Cl}: \\
27.98-34.34 \\
\mathrm{n}=19\end{array}$ & $\begin{array}{c}166 \pm 2.67 \\
95 \% \mathrm{Cl}: 160.76- \\
171.24 \\
n=7\end{array}$ & $\begin{array}{c}162.37 \pm 1.4 \\
95 \% \mathrm{Cl}: 159.62- \\
165.11 \\
n=19\end{array}$ & $\begin{array}{c}25.71 \pm 2.74 \\
95 \% \mathrm{Cl}: \\
20.33-31.09 \\
n=7\end{array}$ & $\begin{array}{c}27.25 \pm 1.48 \\
95 \% \text { Cl: } 24.34- \\
30.16 \\
n=19\end{array}$ \\
\hline$\Sigma$ & $\begin{array}{c}30.64 \pm 0.87 \\
95 \% \mathrm{Cl}: \\
28.94-32.34 \\
\mathrm{n}=44\end{array}$ & $\begin{array}{c}30.43 \pm 0.9 \\
95 \% \mathrm{Cl}: \\
28.66-32.19 \\
\mathrm{n}=47\end{array}$ & $\begin{array}{c}168 \pm 0.8 \\
95 \% \mathrm{Cl}: 166.44- \\
169.56 \\
n=44\end{array}$ & $\begin{array}{c}164.36 \pm 1.38 \\
95 \% \mathrm{Cl}: 161.65- \\
167.07 \\
\mathrm{n}=47\end{array}$ & $\begin{array}{c}24.56 \pm 0.82 \\
95 \% \mathrm{Cl}: \\
22.95-26.18 \\
n=44\end{array}$ & $\begin{array}{c}25.57 \pm 0.91 \\
95 \% \text { Cl: } 23.79- \\
27.35 \\
n=47\end{array}$ \\
\hline $\mathrm{p}$ & 0,505 & 0.51 & 0.281 & 0.239 & 0.552 & 0.129 \\
\hline
\end{tabular}

Table 2. Characteristics of obesity and age of the pregnant woman $\geq 35$ years depending on the location of the placenta

\begin{tabular}{|l|c|c|c|c|c|c|c|c||}
\hline \multirow{2}{*}{ Placenta location } & \multicolumn{4}{|c|}{ Degree of obesity, \% } & \multicolumn{3}{c||}{ Maternal age, years, \% } \\
\cline { 2 - 9 } & Absent & I & II & III & $\Sigma$ & $\geq 35$ & $<35$ & $\Sigma$ \\
\hline Anterior & 39 & $1(1.1 \%)$ & 2 & 2 & 44 & 14 & 33 & 47 \\
& $(42.86 \%)$ & & $(2.2 \%)$ & $(2.2 \%)$ & $(48.35 \%)$ & $(15.38 \%)$ & $(36.26 \%)$ & $(51.65 \%)$ \\
\hline Posterior & 36 & 7 & 2 & 2 & 47 & 13 & 31 & 44 \\
& $(39.56 \%)$ & $(7.69 \%)$ & $(2.2 \%)$ & $(2.2 \%)$ & $(51.65 \%)$ & $(14.29 \%)$ & $(34.07 \%)$ & $(48.35 \%)$ \\
\hline$\Sigma$ & 75 & 8 & 4 & 4 & 91 & 27 & 64 & 91 \\
& $(82.2 \%)$ & $(8.79 \%)$ & $(4.4 \%)$ & $(4.4 \%)$ & $(100 \%)$ & $(29.67 \%)$ & $(70.33 \%)$ & $(100 \%)$ \\
\hline
\end{tabular}

Table 3. Characteristics of maternal preeclampsia factors depending on the location of the placenta

\begin{tabular}{|c|c|c|c|c|}
\hline \multirow{2}{*}{ Maternal factors of PE development } & \multicolumn{2}{|c|}{ Placenta location } & \multirow{2}{*}{$\Sigma$} & \multirow{2}{*}{ Odds ratio, confidence interva } \\
\hline & Posterior & Anterior & & \\
\hline PE during previous pregnancy & $\begin{array}{c}2 \\
(3.64 \%)\end{array}$ & $\begin{array}{c}3 \\
(5.45 \%)\end{array}$ & $\begin{array}{c}5 \\
(9.09 \%)\end{array}$ & $\begin{array}{c}1.38 \\
(95 \% \mathrm{Cl} 0.21-9.01)\end{array}$ \\
\hline$P E$ in the mother & $\begin{array}{c}4 \\
(4.4 \%)\end{array}$ & $\begin{array}{c}4 \\
(4.4 \%)\end{array}$ & $\begin{array}{c}8 \\
(8.79 \%)\end{array}$ & $\begin{array}{c}0.93 \\
(95 \% \mathrm{Cl} 0,22-3.97)\end{array}$ \\
\hline Chronic hypertension & $\begin{array}{c}1 \\
(1,11 \%) \\
\end{array}$ & $\begin{array}{c}2 \\
(2.22 \%) \\
\end{array}$ & $\begin{array}{c}3 \\
(3.33 \%)\end{array}$ & $\begin{array}{c}0.51 \\
(95 \% \mathrm{Cl} 0.04-5.85) \\
\end{array}$ \\
\hline History of renal disease & $\begin{array}{c}10 \\
(10.99 \%)\end{array}$ & $\begin{array}{c}11 \\
(12.09 \%)\end{array}$ & $21(23.08 \%)$ & $\begin{array}{c}0.96 \\
(95 \% \mathrm{Cl} \mathrm{0,36-2.56)}\end{array}$ \\
\hline The first pregnancy & $\begin{array}{c}18 \\
(19.78 \%)\end{array}$ & $\begin{array}{c}18 \\
(19.78 \%)\end{array}$ & $36(39.56 \%)$ & $\begin{array}{c}0.9 \\
(95 \% \text { Cl } 0.39-2.08) \\
\end{array}$ \\
\hline In vitro fertilization & $\begin{array}{c}3 \\
(3.3 \%)\end{array}$ & $\begin{array}{c}2 \\
(2.2 \%)\end{array}$ & $\begin{array}{c}5 \\
(5.49 \%) \\
\end{array}$ & $\begin{array}{c}0.61 \\
(95 \% \mathrm{Cl} 0.1-3.82) \\
\end{array}$ \\
\hline APS & $\begin{array}{c}1 \\
(1.1 \%)\end{array}$ & $\begin{array}{c}1 \\
(1,1 \%)\end{array}$ & $\begin{array}{c}2 \\
(2.2 \%)\end{array}$ & $\begin{array}{c}0.93 \\
(95 \% \text { Cl } 0.06-15.42)\end{array}$ \\
\hline $\begin{array}{l}\text { Interval between pregnancies }>10 \\
\text { years }\end{array}$ & $\begin{array}{c}4 \\
(4.4 \%)\end{array}$ & $\begin{array}{c}4 \\
(4.4 \%)\end{array}$ & $\begin{array}{c}8 \\
(8.79 \%)\end{array}$ & $\begin{array}{c}0.88 \\
(95 \% \mathrm{Cl} 0.22-3.45)\end{array}$ \\
\hline
\end{tabular}

$C$ value of 1.08 is associated with PE sensitivity $87.5 \%$ and specificity level as high as $100 \%$ [8]. When analyzing the ratio of cystatin C level over $1.0 \mathrm{mmol} / \mathrm{I}$ to the anterior location of the placenta, the OR was $3.92(95 \% \mathrm{Cl} 1.45-10.57)$, sensitivity $84.09 \%$, specificity $42.55 \%$, and accuracy $62.64 \%$, $\mathrm{p}=0.011$ (Table 4). It is possible to assume that anterior location of the placenta, is associated with the 3.92 - fold higher probability of increased cystatin C level, which in turn will lead to the development of PE.

When analyzing creatinine level at the preclinical stage of PE statistical difference between anterior $(78.1 \pm 1.8(95 \% \mathrm{Cl}$ : 74.57-81.63)) and posterior (72.84 \pm 4.56 (95 \% Cl: 63), 91$81,77))$ position of placenta was not observed $(p=0.203)$, but the significance was noted for anterior placentation between 
Акушерство та гінекологія -

Table 4. Characteristics of the relationship between cystatin $\mathrm{C}$ and preeclampsia depending on the location of the placenta

\begin{tabular}{|c|c|c|c|c|c|c|}
\hline \multirow{2}{*}{ Placenta location } & \multicolumn{2}{|c|}{ Cystatin C, mg / I } & \multirow{2}{*}{$\Sigma$} & \multicolumn{2}{|c|}{ Preeclampsia } & \multirow{2}{*}{$\Sigma$} \\
\hline & $<1.0$ & $>1,0$ & & Without PE & Without PE & \\
\hline Anterior & $\begin{array}{c}27 \\
(29.67 \%)\end{array}$ & $\begin{array}{c}20 \\
(21.98 \%)\end{array}$ & $\begin{array}{c}47 \\
(51.65 \%)\end{array}$ & $\begin{array}{c}28 \\
(30.77 \%)\end{array}$ & $\begin{array}{c}19 \\
(20.88 \%)\end{array}$ & $\begin{array}{c}47 \\
(51.65 \%)\end{array}$ \\
\hline Posterior & $\begin{array}{c}37 \\
(40.66 \%)\end{array}$ & $\begin{array}{c}7 \\
(7.69 \%)\end{array}$ & $\begin{array}{c}44 \\
(48.35 \%)\end{array}$ & $37(40.66 \%)$ & $\begin{array}{c}7 \\
(7.69 \%)\end{array}$ & $\begin{array}{c}44 \\
(48.3 \%)\end{array}$ \\
\hline$\Sigma$ & $\begin{array}{c}64 \\
(70.33 \%)\end{array}$ & $\begin{array}{c}27 \\
(29.67 \%)\end{array}$ & $\begin{array}{c}91 \\
(100 \%)\end{array}$ & $\begin{array}{c}65 \\
(71.43 \%)\end{array}$ & $26(28.57 \%)$ & $\begin{array}{c}91 \\
(100 \%)\end{array}$ \\
\hline \multicolumn{4}{|c|}{ Pearson criterion, $x 2=6.51, p=0.011$} & \multicolumn{3}{|c|}{ Pearson criterion, $x 2=5.55, p=0.019$} \\
\hline
\end{tabular}

women with and without PE $(70.92 \pm 2.25$ (95 \% Cl: $66.51-$ 75.33) ), $p=0.026$. Urea levels in the preeclamptic group are statistically significant between posterior (4.97 \pm 1.31 (95\% $\mathrm{Cl}: 2.41-7.54)$ and anterior placentation groups (3.19 \pm 0.19 (95 \% Cl): 2.82-3.55) ( $p=0.041)$ However, creatinine and urea levels do not exceed the reference values; therefore, this parameter is not applicable for PE screening (Fig. 1).

When analyzing the frequency of preeclampsia in patients with anterior location of the placenta, the OR was 3.59 (95\% Cl 1.32-9.71) with statistical significance $p=0.019$ (Table 4). When using the anterior location of the placenta as a screening marker of PE, sensitivity $84.09 \%$, specificity $40.43 \%$, frequency of positive predictions $56.92 \%$ and negative predictions $73.08 \%$, accuracy $61.54 \%$ were reported.

Preeclampsia is a multisystem syndrome that leads not only to maternal and perinatal complications and mortality during pregnancy and childbirth, but also has an impact on the development of diseases such as chronic renal and cardiovascular failure, hypertension and diabetes at a later date [9-11]. Thus, this leads to the need to investigate the screening markers of PE and pay special attention to the most available tests. The use of ultrasound during the second trimester of pregnancy is economically justified and routinely used in everyday practice.

The uterine arteries give branches that give supply for different parts of the uterus and play an important role in maintaining blood supply during uterine growth during pregnancy [12]. In the research of Kozlov S.V et al., asymmetry of blood supply of the right and left halves of the uterus and inequality of arterial inflow to the anterior and posterior walls of the uterus were revealed [13]. It is possible to assume that there is an incomplete trophoblastic invasion of a placenta that leads to complications of pregnancy, including PE. Some researchers have described the effects of lateral placentation. Nair $V$.V. et al. suggest that maternal and neonatal complications are more likely to occur in association with lateral placentation compared to the central location and associate PE with the right side placenta position [14]. The risk of hypertension development during pregnancy with lateral placenta position in the studies of Prathima A. and Reddi Rani P. was: OR 3.5 (95 \% Cl 1.4-8.6) with a sensitivity $28.1 \%$ and a specificity level $87.6 \%$ [15].

In the analysis of Keshavarz $\mathrm{E}$ et al. lateral placenta position was associated with preeclampsia in $47.6 \%$ (20 of 42) cases, while other locations were associated with preeclampsia in $30 \%$ of patients (101 of 337) ( $p=0.02$, OR 2.1, $95 \% \mathrm{Cl}: 1.1-4.1)$. In the group of preeclampsia the right lateral placenta position was more often observed, and in the normal group the left lateral placenta position was common [16]. This is consistent with other studies which suggest that the lateral location of the placenta is associated with an increased risk of preeclampsia [17-19].

In contrast to these studies, Salama-Bello R. et al. did not report any difference in the incidence of hypertensive disorders during pregnancy between patients with central and lateral placenta position [20]. PE and severe hypertension were more common in patients with posterior placentation; the analysis of Prathima A and others, involved only 11

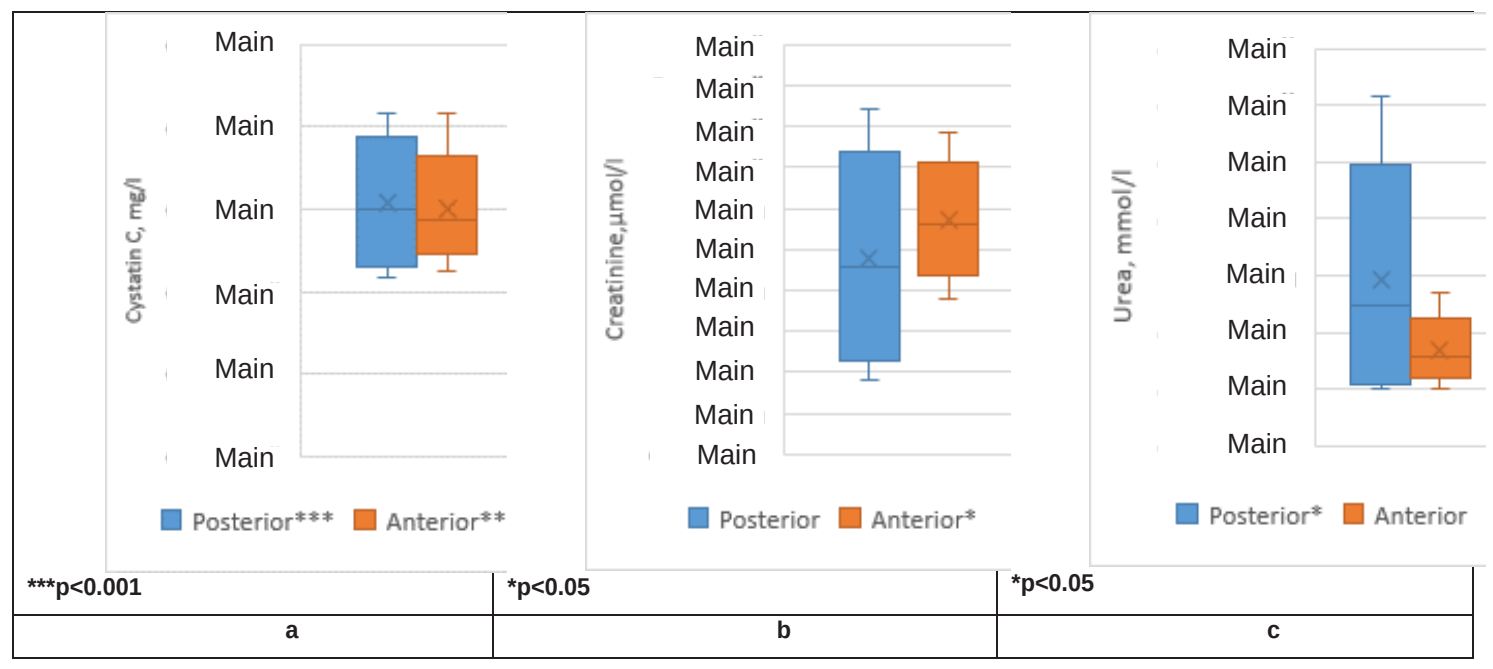

Fig. 1. Serum Cystatin C (а), Creatinine (в) and Urea (c) in pregnant women with preeclampsia depending on the location of the placenta 
women with PE; therefore the results of this study are not statistically significant [15].

Jenabi $\mathrm{E}$ et al. in a meta-analysis of nine studies have demonstrated that the chances of preeclampsia were 0.55 (95\% Cl: 0.26-0.85) in cases of placenta previa compared to control groups and $0.17(95 \% \mathrm{Cl} 0.07-0.27)$ in studies with variable adjustment. Thus, placenta previa has been shown to be associated with a reduction in the incidence of preeclampsia [21]. This may be due to the abundant blood supply, which in turn contributes to adequate trophoblast invasion.

Thus, research data on the relationship between placenta location and PE development are contradictory and require additional investigation.

In our study, attention was paid to the anterior and posterior location of the placenta, which was determined during the second ultrasound screening, and the prevalence of PE in these groups; use of this predictor as a part of complex screening has been considered.

In this study that enrolled 91 pregnant women, PE has developed in 26 (28.57\%) females, of whom 19 (20.88\%) had anterior placenta position, while 7 (7.69 \%) had a posterior placental location. We found that the risk of PE is 3.59 times higher in patients with the anterior location compared

\section{LITERATURE}

1. Poon L. C. The International Federation of Gynecology and Obstetrics (FIGO) initiative on pre-eclampsia: A pragmatic guide for first-trimester screening and prevention / L. C. Poon, A. Shennan, J. A. Hyett [et al.] // Int. J. Gynecol. Obstet. - 2019. - Vol. 145 (Suppl 1). - P. 1-33.

2. Sotiriadis A. ISUOG Practice Guidelines: role of ultrasound in screening for and follow-up of pre-eclampsia / A. Sotiriadis, E. Hernandez-Andrade, F. Silva Costa [et al.] // Ultrasound Obstet. Gynecol. - 2019. - Vol. 53, No.1. - P. 7-22.

3. Khong L. S. First-Trimester uterine artery doppler analysis in the prediction of later pregnancy complications [electronic resource] / L. S. Khong, C. S. Kane, P. S. Brennecke, F. da Silva Costa // Disease Markers. - 2015.

4. O'Gorman N. Accuracy of competing- risks model in screening for pre-eclampsia by maternal factors and biomarkers at 11-13 weeks'gestation / N. O'Gorman, D. Wright, L. C. Poon [et al.] // Ultrasound Obstet. Gynecol. - 2017. Vol. 49. - P. 751-755.

5. Rana S. Preeclampsia pathophysiology, challenges, and perspectives / S. Rana, E. Lemoine, J. P. Granger, S. A. Karumanchi // Circ. Res. - 2019. - Vol. 124, No.7. - P. 1094-1112.

6. Ojha K. Placental pathology in severe pre-eclampsia and eclampsia / K. Ojha, S. Rawal, A. Jha // Nep. Med. J. - 2018. - Vol. 1 (1). - P. 32-35.

7. Brown M. A. The hypertensive disorders of pregnancy: ISSHP classification, diagnosis and management recommendations for international practice / M. A. Brown, L. A. Magee, L. C. Kenny [et al.] // Pregnancy Hypertens. - 2018. - Vol. 13. - P. 291-310.

8. Марічереда В. Г. Пріоритетність цистатину С поміж ниркових біомаркерів в діагностиці прееклампсії / В. Г. Марічереда, М. Ю. Голубенко, Л. І. Берлінська // Нирки. - 2020. - № 9 (2). - P. 87-91.

9. Feig D. S. Preeclampsia as a risk factor for diabetes: a population-based cohort study / D. S. Feig, B. R. Shah, L. L. Lipscombe [et al.] // PLoS Med. - 2013. - Vol. 10 (4). P. e1001425. to patients with the posterior location $(p=0.019)$. Our findings are consistent with other authors who link the anterior placenta to PE with a statistical significance of $p<0.001[22$, 23]. Anterior placenta locations is not related to other maternal factors, but is statistically significant in combination with the renal biomarker of acute renal damage, cystatin $\mathrm{C}$ level $(p=0.011)$, for prediction of PE.

Rationale for the use of cystatin $C$ level assessment in PE screening was demonstrated in our previous study, the value is statistically significant $(p<0.001)$ and the value is over than 1.08 is a reliable marker of preeclampsia at the preclinical stage of implementation [24].

CONCLUSIONS. 1. The risk of preeclampsia is 3.59 folds higher in patients with the anterior location of placenta.

2. Determining the anterior location of the placenta during ultrasound screening during the second trimester of pregnancy can predict the development of preeclampsia with an accuracy level $61.54 \%$.

3. The use of ultrasound is an economical, non-invasive and available method of diagnosis.

4. To increase the prognostic significance for the detection of preeclampsia in women with anterior location of the placenta, it is recommended to assess the serum level of cystatin $\mathrm{C}$.

10. Hypertensive disorders of pregnancy and subsequent maternal cardiovascular health / N. E. Bergen, S. SchalekampTimmermans, J. Roos-Hesselink [et al.] // Eur. J. Epidemiol. - 2018. - Vol. 33. - P. 763-771.

11. Lopes V. A. Prevalence of chronic kidney disease after preeclampsia / V. A. Lopes, J. J. Spaan, T. Cornelis // J. Nephrol. - 2017. - Vol. 30. - P. 403-409.

12. Chaudhry R. Anatomy, abdomen and pelvis, uterine arteries / R. Chaudhry, K. Chaudhry. - Treasure Island (FL): StatPearls Publishing, 2020.

13. Вариантная анатомия артерий матки / С. В. Козлов, Д. Д. Дворецкий, Л. А. Алексеенко [и др.] // Український журнал медицини, біології та спорту. - 2018. - Т. 3, № 4 (13). - C. 32-37.

14. Nair V. V. Study of placental location and pregnancy outcome / V. V. Nair, S. S. Nair, K. Radhamany // Int. J. Reprod. Contracept. Obstet. Gynecol. - 2019. - Vol. 8 (4). - P. 1393-1397.

15. Prathima A. Association of placental position with the development of hypertension in pregnancy / A. Prathima, P. Reddi Rani // Int. J. Reprod. Contracept. Obstet. Gynecol. 2019. - Vol. 8 (1). - P. 238-242.

16. Prediction of pre-eclampsia development by placenta location: a simple predictor / E. Keshavarz, A. Sadeghian, A. G. Hakemi, F. T. Khtibi // J. Obstet. Gynecol. Cancer. Res. 2017. - Vol. 2 (4). - P. e11945.

17. Placental location and development of preeclampsia: a longitudinal study / A. Priyadarshini, P. Upreti, R. Nautiyal, M. Goyal // Int. J. Reprod. Contracept. Obstet. Gynecol. - 2019. - Vol. 8 (4).

18. Sandhya K. Placental laterality as a predictor of preeclampsia / K. Sandhya, G. B. Madhavi, M. Chandramathi // Am. J. Phytomed. Clin. Ther. - 2015. - Vol. 3 (3). - P. 231-236.

19. Lateral placenta as a predictor for development of preeclampsia / A. Rai, A. Thatal, B. K. Sharma, Y. Narwat // Indian J. Obstet. Gynecol. Res. - 2020. - Vol. 7 (2). - P. 216-221.

20. Placental location and the development of hypertensive disorders of pregnancy / R. Salama-Bello, J. R. Duncan, 
S. L. Howard [et al.] // J. Ultrasound Med. - 2019. - Vol. 38. P. $173-177$.

21. Jenabi E. The association between placenta previa and pre-eclampsia: a meta-analysis / E. Jenabi, Y. Veisani, S. Khazae // Erciyes Med. J. - 2020. - Vol. 42 (1). - P. 3-6.

22. Zia S. Placental location and pregnancy outcome / S. Zia // J. Turkish-German Gynecol Assoc. - 2013. - Vol. 14. - P. 190-193.

\section{REFERENCES}

1. Poon, L.C., Shennan, A., Hyett, J.A., Kapur, A., Hadar, E., Divakar, H., ..., \& Hod, M. (2019). The International Federation of Gynecology and Obstetrics (FIGO) initiative on pre-eclampsia: A pragmatic guide for first-trimester screening and prevention. Int. J. Gynecol. Obstet., 145 (S1), 1-33. DOI:10.1002/ijgo.12802.

2. Sotiriadis, A., Hernandez-Andrade, E., da Silva Costa, F., Ghi, T., Glanc, P., Khalil, A., ..., \& Thilaganathan, B. (2019). ISUOG Practice Guidelines: role of ultrasound in screening for and follow-up of pre-eclampsia. Ultrasound. Obstet. Gynecol., 53 (1), 7-22. DOI:10.1002/uog.20105.

3. Khong, L.S., Kane, C.S, Brennecke, P.S, \& da Silva Costa, F. (2015). First-trimester uterine artery doppler analysis in the prediction of later pregnancy complications. Dis. Markers. DOI:10.1155/2015/679730.

4. O'Gorman, N., Wright, D., Poon, L.C., Rolnik, D.L., Syngelaki, A., Wright, A., .., \& Nicolaides, K.H. (2017). Accuracy of competing-risks model in screening for pre-eclampsia bymaternal factors and biomarkers at $11-13$ weeks'gestation. Ultrasound. Obstet. Gynecol, 49, 751-755. DOI:10.1002/uog.17399.

5. Rana, S., Lemoine, E., Granger, J.P., \& Karumanchi, S.A. (2019). Preeclampsia pathophysiology, challenges, and perspectives. Circ. Res., 124 (7), 1094-1112. DOI:10.1161/ CIRCRESAHA.118.313276.

6. Ojha, K., Rawal, S., \& Jha, A. (2018). Placental pathology in severe pre-eclampsia and eclampsia. Nep. Med. J., 1 (1), 32-35.

7. Brown, M.A., Magee, L.A., Kenny, L.C. , Karumanchi, S.A., McCarthy, F.P., Saito, S., ..., \& Ishaku, S. (2018). The hypertensive disorders of pregnancy: ISSHP classification, diagnosis and management recommendations for international practice. Pregnancy Hypertens., 13, 291-310. DOI:10.1016/j.preghy.2018.05.004.

8. Marichereda, V.G., Holubenko, M.Yu., \& Berlinska, L.I. (2020). Priorytetnist cystatynu C pomizh nyrkovyx biomarkeriv $\mathrm{v}$ diagnostyci preeklampsiyi [Priority of cystatin $\mathrm{C}$ among other renal biomarkers for pre-eclampsia diagnosing]. Počki-Kidney, 9 (2), 87-91. DOI:10.22141/2307-1257.9.2.2020 [in Ukrainian]

9. Feig D.S., Shah B.R., Lipscombe L.L., Wu C.F., Ray J.G. et al. (2013) Preeclampsia as a risk factor for diabetes: a population-based cohort study. PLoS Med., 10 (4), e1001425. DOI:10.1371/journal.pmed.1001425.

10. Bergen, N.E., Schalekamp-Timmermans, S., RoosHesselink, J., Roeters van Lennep, J.E., Jaddoe, V.V.W., \& Steegers, E.A.P. (2018). Hypertensive disorders of pregnancy and subsequent maternal cardiovascular health. Eur. J. Epidemiol., 33, 763-771. DOI:10.1007/s10654-018-0400-1.

11. Lopes, V.A., Spaan, J.J., \& Cornelis, T. (2017). Prevalence of chronic kidney disease after preeclampsia. J. Nephrol., 30, 403-409. DOI:10.1007/s40620-016-0342-1.

12. Chaudhry, R., \& Chaudhry, K. (2020). Anatomy, abdo-
23. Placental location, postpartum hemorrhage and retained placenta in women with a previous cesarean section delivery: a prospective cohort study / J. Belachewa, K. Eureniusa, A. MulicLutvicaa, O. Axelsson // Upsala J. Med. Sci. - 2017. - Vol. 122 (3). - Р. 185-189.

24. Марічереда В. Г. Значущість цистатину С в доклінічній діагностиці прееклампсії у вагітних / В. Г. Марічереда, І. 3. Гладчук, Л. І. Берлінська // Актуальні питання педіатрії, акушерства та гінекології. - 2019. - №. 2. - С. 133-137.

men and pelvis, uterine arteries. Treasure Island (FL): StatPearls Publishing, 2020.

13. Kozlov, S.V., Dvoretskii, D.D., Alekseenko, L.A., Omelchenko, A., \& Kartamysheva, V.D. (2018). Variantnaya anatomiya arteriy matki [Anatomical variants of uterine arteries]. Ukrainskyi zhurnal medytsyny, biolohii ta sportu - Ukrainian Journal of Medicine, Biology and Sport, 3, 4 (13), 32-37 [in Russian].

14. Nair, V.V., Nair, S.S., \& Radhamany, K. (2019). Study of placental location and pregnancy outcome. Int. J. Reprod. Contracept. Obstet. Gynecol., 8 (4), 1393-1397.

15. Prathima, A., \& Reddi Rani, P. (2019). Association of placental position with the development of hypertension in pregnancy. Int. J. Reprod. Contracept. Obstet. Gynecol., 8 (1), 238-242.

16. Keshavarz, E., Sadeghian, A., Hakemi, A.G., \& Khtibi, F.T. (2017). Prediction of pre-eclampsia development by placenta location: a simple predictor. J. Obstet. Gynecol. Cancer. Res., 2 (4), e11945.

17. Priyadarshini, A., Upreti, P., Nautiyal, R., \& Goyal, M. (2019). Placental location and development of preeclampsia: a longitudinal study. Int. J. Reprod. Contracept. Obstet. Gynecol., 8 (4), DOI:10.18203/2320-1770.ijrcog20191005.

18. Sandhya, K., Madhavi, G.B., \& Chandramathi, M. (2015). Placental laterality as a predictor of preeclampsia. Am. J. Phytomed. Clin. Ther., 3 (3), 231-236. DOI:10.1007/s13224-012-0241-X.

19. Rai, A., Thatal, A., Sharma, B.K., \& Narwat, Y. (2020). Lateral placenta as a predictor for development of preeclampsia. Indian J. Obstet. Gynecol. Res., 7 (2), 216-221.

20. Salama-Bello, R., Duncan, J.R., Howard, S.L., Song, J., \& Schenone, M.H. (2019). Placental location and the development of hypertensive disorders of pregnancy. J. Ultrasound. Med., 38, 173-177. DOI:10.1002/jum.14681.

21. Jenabi, E., Veisani, Y., \& Khazae, S. (2020). The association between placenta previa and pre-eclampsia: a metaanalysis. Erciyes Med. J., 42 (1), 3-6.

22. Zia, S. (2013). Placental location and pregnancy outcome. J. Turkish-German Gynecol. Assoc., 14, 190-193. DOI:10.5152/jtgga.2013.92609.

23. Belachewa, J., Eureniusa, K., Mulic-Lutvicaa, A., \& Axelsson, O. (2017). Placental location, postpartum hemorrhage and retained placenta in women with a previous cesarean section delivery: a prospective cohort study. Upsala J. Med. Sci., 122 (3), 185-189. DOI: 10.1080/03009734.2017.1356405.

24. Marichereda, V.G., Gladchuk, I.Z., \& Berlinska, L.I. (2019). Znachushhist tsystatynu C v doklinichnii diahnostytsi preeklampsii u vahitnykh [The significance of cystatine $\mathrm{C}$ in pre-clinical diagnosing of pre-eclampsia in pregnant women]. Aktualni pytannia pediatrii, akusherstva ta hinekolohii - Actual Problems of Pediatrics, Obstetrics and Gynecology, 2, 133-137. DOI:10.11603/24116-4944.2019.2.10933 [in Ukrainian]. 